\title{
Herbicide tolerance and gene silencing stability over generations in the ricin bio- detoxicated castor bean
}

\author{
Natália L. de Sousa®, Glaucia B. Cabral@ and Francisco J. L. Aragão* (1)
}

\begin{abstract}
Castor bean (Ricinus communis L.) is an important cultivated oilseed. Seeds contain ricinoleic acid, a valuable product for a variety of industries. Castor cake is a residue of ricinoleic manufacture and could be used as animal feed due to its high amount of protein. However, castor cake contains ricin and RCA $_{120}$, both highly toxic and allergenic proteins. In 2017, we reported the development of a transgenic event (named TB14S-5D) with an undetectable amount of ricin/RCA 120 In the present work, we evaluate TB14S-5D for tolerance to the herbicide imazapyr, as it contains the selectable marker gene, ahas, which was previously isolated from Arabidopsis thaliana and contains a mutation at position $653 \mathrm{bp}$. In addition, we demonstrated that the ricin coding genes are stably silenced over three generations.
\end{abstract}

Keywords: Imazapyr, Ricinus communis, Transgenic castor bean

\section{Introduction}

Castor bean (Ricinus communis L.) is an oilseed found worldwide and commonly cultivated in tropical and subtropical regions. India, Mozambique, China, and Brazil are the major producers. India is responsible for about $80 \%$ of the world's production [1]. Castor oil is the most important product, with great value in industry, especially to produce lubricants, medicines, and cosmetics, as it contains high amounts of ricinoleic acid, a viscous and highly stable fatty acid [2].

Castor cake is the by-product generated after oil extraction. It is mainly used as a fertilizer and soil conditioner. However, it could also be used in animal feed because it contains high amounts of protein and essential amino acids. Nevertheless, it is extremely toxic due to the presence of the highly toxic/allergenic proteins, ricin and $\mathrm{RCA}_{120}[3,4]$. Ricin is a highly toxic ribosome-inactivating protein (RIP) present in castor seeds' endosperm, formed by two chains. Chain B is a lectin that binds to

*Correspondence: francisco.aragao@embrapa.br

Embrapa Recursos Genéticos e Biotecnologia, PqEB W5 Norte, Brasília, DF 70770-900, Brazil glycoproteins/glycolipids present on the cell surface and that allows ricin to enter animal cells. Chain A inactivates the ribosomes by depurination of one adenosine in the conserved loop on the $28 \mathrm{~S}$ rRNA subunit, resulting in cell death [5]. $\mathrm{RCA}_{120}$ is a strong hemagglutinin, composed of two A chains and two B chains, highly similar to ricin (90 and $84 \%$, respectively) [3].

The demand for castor products has increased, leading to the need for increased production/yield [6]. Castor crop yield is affected by several factors, such as weed management, which is a challenge, since castor is very sensitive to competition and initially takes time to grow, in contrast to weeds, which grow faster [6]. To control weeds in large crops, several agronomic practices must be taken into account. However, mechanical control is very expensive, and the use of herbicides is more efficient, especially if herbicides with a distinct mode of action are used [6, 7].

We generated an RNA interference-mediated ricinsilenced castor bean event, named TB14S-5D [8]. The vector pRicRNAi used to generate the event contained an intron hairpin cassette to silence ricin and the gus gene (coding for a $\beta$-glucuronidase) and the mutated 
Atahas gene (coding for an acetohydroxyacid synthase, with a mutation at position $653 \mathrm{bp}$ resulting in a serine to asparagine substitution), which confers tolerance to imidazolinone herbicides [9]. The $\mathrm{T}_{1}$ generation showed an undetectable amount of ricin in seeds and no hemagglutination activity [8]. In addition, seed protein extracts were not toxic to both IEC- 6 cells and mice. $T_{1}$ progeny also revealed high expression of gus and in vitro tolerance to imazapyr. This class of herbicides inhibits the activity of the AHAS enzyme, impairing the biosynthesis of isoleucine, leucine, and valine [10].

This work aims to evaluate the tolerance of the transgenic event TB14S-5D to imidazolinone, as well as the stability of ricin/RCA 120 silenced, and gus expression in subsequent generations.

\section{Materials and methods}

\section{Test for tolerance to imazapyr}

The transgenic castor bean line (named TB14S-5D) used in this study was previously generated as described by Sousa et al. [8]. It was obtained by embryonic axes bombarded with the vector pRicRNAi (Fig. 1).

Seeds collected from non-transgenic and $T_{3}$ generation of transgenic lines were sown in $5 \mathrm{dm}^{3}$ plastic pots containing fertilized soil. Twenty-one-day-old plantlets were sprayed with the herbicide (imazapyr) (using a solution of $1 \mathrm{~g} / \mathrm{L}$ ) at the final dose of $100 \mathrm{~g} \mathrm{ha}^{-1}$ and $250 \mathrm{~g} \mathrm{ha}^{-1}$, observed and photographed after 75 days. Seven transgenic and non-transgenic (wild type; WT) plants were used for each herbicide concentration, evaluated under greenhouse conditions. Experiment was repeated twice.

\section{Quantification of ricin content}

Quantification of ricin content in mature seeds of the transgenic event TB14S-5D [generations $T_{1}, T_{2}$ and $T_{3}$ (homozygous)] was carried out using ELISA [11]. The homozygosis was verified by testing 30 plants from the $\mathrm{T}_{3}$ generation for the gus gene expression. For protein extraction, $200 \mathrm{mg}$ of tissue (endosperm) was ground in liquid nitrogen and vortexed in $600 \mu \mathrm{L}$ of phosphatebuffered saline (PBS) for $30 \mathrm{~min}$ at $4^{\circ} \mathrm{C}$. The mixture was centrifuged at $20,800 \mathrm{~g}$ for $60 \mathrm{~min}$ at $4^{\circ} \mathrm{C}$, and the aqueous phase was collected. Total protein was quantified using the Quick Start Bradford Protein Assay (Bio-Rad Laboratories). For ricin detection, goat antiserum (Santa Cruz Biotechnology) was used, raised against a peptide located at the $\mathrm{N}$-terminus of the ricin precursor. A standard curve was produced using purified ricin A (Sigma, L9514). The limit of detection was determined as $80 \mathrm{pg} /$ $\mu \mathrm{g}$ total protein in the $50 \mu \mathrm{L}$ well. Absorbance was measured in a microplate reader (Bio-Rad) at $405 \mathrm{~nm}$.

\section{Hemagglutination assay}

Hemagglutination assay was carried out in a 96-well microtiter plate [8]. Total proteins from endosperm of transgenic and non-transgenic seeds were extracted as previously described. Each well contained $50 \mu \mathrm{L}$ phosphate-buffered saline (PBS) and $50 \mu \mathrm{L}$ of $\mathrm{RCA}_{120}$ (initial concentration of $0.1 \mu \mathrm{g} / \mu \mathrm{L}), 50 \mu \mathrm{L}$ total proteins isolated from transgenic and non-transgenic castor bean endosperm serially diluted by a ratio of $1 / 2$ starting with $2 \mu \mathrm{g}$ total protein $/ \mu \mathrm{L}$. The blank was made with $50 \mu \mathrm{L}$ PBS. Fifty microliters of a $2 \%$ suspension (diluted in $0.15 \mathrm{M} \mathrm{NaCl}$ ) of cow (Bos indicus) red blood cells were added to each well and gently mixed. Plates were incubated at room temperature for $2 \mathrm{~h}$, and results were recorded. The titer was expressed as the reciprocal of dilution factor of the last well showing hemagglutination activity. Samples were observed using an inverted microscope.

\section{Beta-glucuronidase (GUS) histochemical assay}

Leaf tissues were analyzed for in situ localization of GUS activity [12].

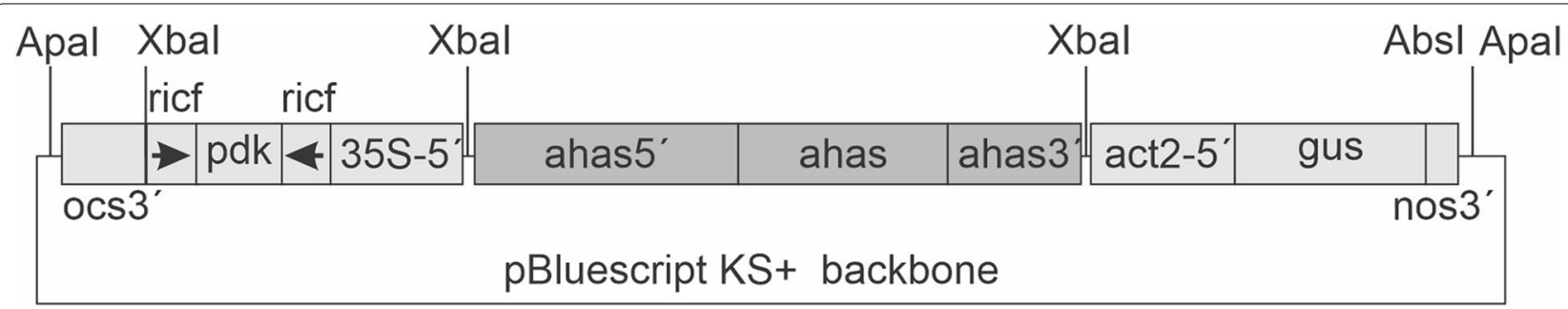

Fig. 1 Diagram representing the vector pRicRNAi used to obtain the transgenic castor bean event TB14S-5D. The vector contains the ahas gene (ahas5': ahas gene promoter; ahas: A. thaliana AHAS coding sequence; ahas3': ahas gene terminator), the intron-hairpin cassette to silence ricin endogenous genes (35S-5': 35 S promoter of Cauliflower mosaic virus; pdk: Flaveria trinervia pdk intron; ocs3': octopine synthase terminator from Agrobacterium tumefaciens, ricf: 460-bp ricin gene fragments cloned in sense and antisense orientations) and the gus gene (act2-5': actin 2 promoter from A. thaliana; gus: $\beta$-glucuronidase coding region; nos3': nopaline synthase terminator from A. tumefaciens) 


\section{Statistical analysis}

Data were analyzed by analysis of variance (ANOVA) at $p<0.01$ followed by Dunnett's test to compare between treatments as implemented in GraphPad Prism 6.0 software.

\section{Results and discussion}

We reported here the tolerance of transgenic castor bean to herbicidal molecule imazapyr (imidazolinone) using a mutated Atahas gene from A. thaliana. Transgenic plants treated with $100 \mathrm{~g} / \mathrm{ha}$ of imazapyr presented no symptoms of intoxication (Fig. 2b). In contrast, WT plants treated with the same concentration started to present multiple shoots in the apical meristem (Fig. 2e). At $250 \mathrm{~g} /$ ha of Imazapyr, non-transgenic plants presented symptoms of red vein and death of apical meristems (Fig. 2f). In contrast, the transgenic line presented tolerance up to $250 \mathrm{~g} / \mathrm{ha}$ of Imazapyr, showing only signs of multiple shoots in the apical meristem (Fig. 2c). All WT plants treated with $250 \mathrm{~g} / \mathrm{ha}$ of Imazapyr died after 75 days, and the transgenic plants remained healthy, and normally growing (Fig. $2 \mathrm{f}, \mathrm{c}$ ), similar to the transgenic and nontransgenic plants with no herbicide applied (Fig. 2a, d). There is a considerable interest in generating herbicide tolerant castor bean varieties. Imidazolinone tolerance was achieved by both conventional and molecular breeding in rice, soybean, sugar beet, cowpea, and sugarcane [9, 13-17]. The event TB14S-5D showed high tolerance to $250 \mathrm{gha}^{-1}$ imazapyr, which is 3.5 -fold the commercial recommended dose for weed control. Additionally, we have previously demonstrated that this line presented a Mendelian segregation in the $F_{1}$ generation [8]. It makes the transgene easier to transfer to other genotypes. Although event TB14S-5D has yet to be tested under field conditions, there is the prospect that its cultivation can be used as an efficient tool as part of a weed control strategy.

No agglutination was observed in red blood cells (RBCs) incubated with transgenic seed protein extract ( $\mathrm{T}_{1}, \mathrm{~T}_{2}$, or $\mathrm{T}_{3}$ generations) (Fig. $3 \mathrm{a}$ ), which shows the stably silenced $\mathrm{RCA}_{120}$. In contrast, hemagglutination was observed with purified $\mathrm{RCA}_{120}$ and WT proteins (Fig. 3a). ELISA was not able to detect ricin/ $\mathrm{RCA}_{120}$ proteins from seeds of the TB14S-5D $\mathrm{T}_{1}, \mathrm{~T}_{2}$, and $\mathrm{T}_{3}$ generations (Fig. 3b). Moreover, the TB14S-5D $\mathrm{T}_{3}$ and $\mathrm{T}_{4}$ generations (homozygous plants) showed strong gus expression in leaves (Fig. 4). Homozygosity was determined by testing 30 plants from the $\mathrm{T}_{3}$ generation for gus gene expression, which showed that all of them were positive (data not shown).

RNAi is an important tool in plant science and has been shown to be effective in silencing genes stably. In 2007, a transgenic common bean event resistant to bean golden mosaic virus (BGMV) using the RNAi strategy was developed [18]. After 17years and over more than 24 generations, the transgenic event presents stable RNA silencing and resistance to $B G M V$, including in commercial areas (Thiago L.P.O Souza, Embrapa, Personal
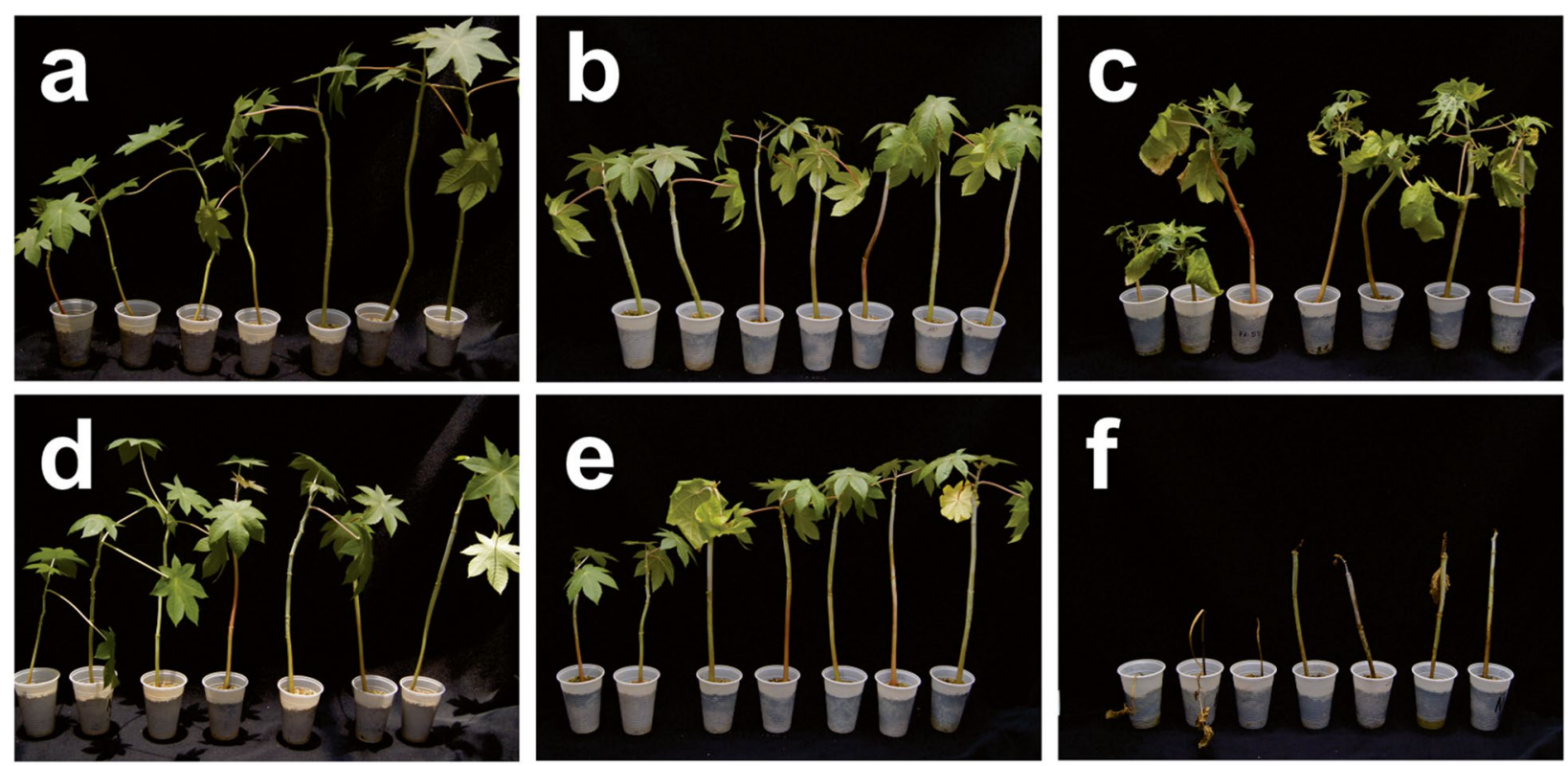

Fig. 2 Evaluation of transgenic castor bean event TB14S-5D at 75 days post application of herbicide. Twenty-one day-old plantlets from the transgenic (a-c) and non-transgenic (d-f) lines. Plantlets were sprayed with $0 \mathrm{~g} \mathrm{ha}^{-1}(\mathbf{a}$ and $\mathbf{d}), 100 \mathrm{~g} \mathrm{ha}^{-1}$ (b and e), $250 \mathrm{~g} \mathrm{ha}^{-1}$ (c and $\left.\mathbf{f}\right)$ imazapyr 

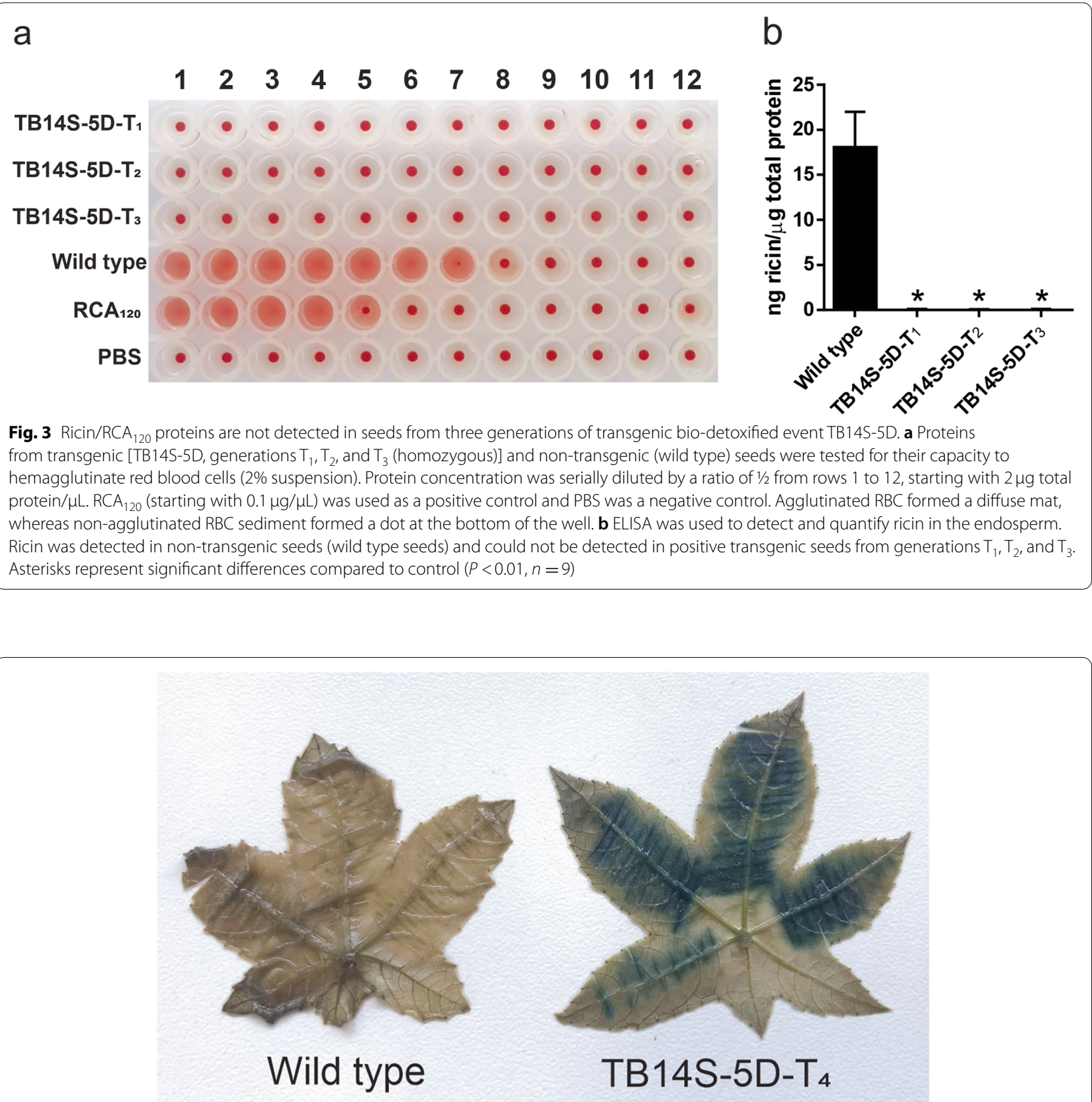

Fig. 4 Expression of the gus gene in transgenic leaf from the 4th generation of event TB14S-5D (homozygous plants). Wild type is a leaf from the non-transgenic line. Leaves were cut to assist substrate penetration

communication). In addition, RNAi has been an effective tool to generate transgenic crops resistant to insect pests, with the development of some commercial products [19].

\section{Conclusions}

Collectively, our results demonstrated that event TB14S$5 \mathrm{D}$ is tolerant to the herbicide imazapyr and that ricin/ $\mathrm{RCA}_{120}$ silencing is stable over three generations. This technology is a foundation for safer cultivation and industrial use of castor bean. Herbicide tolerance will help cultivation and harvesting of large areas. In addition, stable ricin/RCA 120 silencing will allow castor cake to be used as an alternative animal foodstuff, due to its high nutritional value. Efforts are being made to evaluate event TB14S-5D under field conditions, as well as to introduce this trait to the breeding program and carry out biosafety 
analyses. This biotechnology will have a major impact on castor bean cultivation, allowing the production of ricinolein oil and protein sources for animal feeding in semiarid and marginal areas, where the cultivation of other crops is difficult.

\section{Abbreviations}

AHAS: Acetohydroxyacid synthase; GUS: $\beta$-Glucuronidase; IEC-6: Rat intestinal epithelial cell line; PBS: Phosphate-buffered saline; RBC: Red blood cells; RCA ${ }_{120}$ : R. communis agglutinin; RIP: Ribosome-inactivating protein; RNAi: RNA interference; WT: Wild type.

\section{Acknowledgements}

The authors would like to acknowledge CNPq (Conselho Nacional de Desenvolvimento Científico e Tecnológico, Brazil) for funding the research and CAPES (Coordenação de Aperfeiçoamento de Pessoal de Nível Superior, Brazil) for providing a fellowship to N. Sousa.

\section{Authors' contributions}

NLS: performed the experiment, analyzed the results, and wrote the manuscript. GBC: analyzed the results and wrote the manuscript. FJLA: conceptualized the idea, analyzed the results, and wrote the manuscript. The authors read and approved the final manuscript.

\section{Funding}

This work was financially supported by Conselho Nacional de Desenvolvimento Científico e Tecnológico (CNPq, Brazil), grant numbers 479848/2007-6 and 454692/2014-5. The funds were utilized for purchasing instruments, chemicals, and other consumables required for the project.

\section{Availability of data and materials}

The datasets used and/or analyzed during the current study are available from the corresponding author on reasonable request.

\section{Declarations}

Ethics approval and consent to participate

Not applicable

\section{Consent for publication}

Not applicable

\section{Competing interests}

The authors declare that they have no competing interests.

Received: 20 July 2021 Accepted: 18 January 2022

Published online: 28 January 2022

\section{References}

1. FAOSTAT (2021). Crops and livestock products. Food and Agriculture Organization of the United Nations. <http://www.faostat.fao.org>, Accessed 28 May 2021.

2. Patel VR, Dumancas GG, Viswanath LCK, Maples R, Subong BJJ (2016) Castor oil: properties, uses, and optimization of processing parameters in commercial production. Lipid Insights 9:1-12. https://doi.org/10.4137/ LPI.S40233

3. Harley SM, Beevers H (1986) Lectins in castor bean seedlings. Plant Physiol 80:1-6

4. Ashfaq MA, Reddy PSS, Kumar CA, Selvaraj VM, Kumar VD (2018) Ricin and RCA - the enemies within castor (Ricinus communis $L$.): a perspective on their biogenesis, mechanism of action, detection methods and detoxification strategies. In: Kole C, Rabinowicz P (eds) The castor bean genome. Compendium of Plant Genomes. Springer International Publishing, pp 215-235. https://doi.org/10.1007/978-3-319-97280-0_12
5. Polito L, Bortolotti M, Battelli MG, Calafato G, Bolognesi A (2019) Ricin: an ancient story for a timeless plant toxin. Toxins 11:324. https://doi.org/10. 3390/toxins11060324

6. Severino LS, Auld DL, Baldanzi M, Cândido MJD, Chen G, Crosby W, Tan D, He X, Lakshmamma P, Lavanya C, Machado OLT, Mielke T, Milani M, Miller TD, Morris JB, Morse SA, Navas AA, Soares DJ, Sofiatti V, Wang ML, Zanotto MD, Zieler H (2012) A review on the challenges for increased production of castor. Agron J 104:853-880. https://doi.org/10.2134/agronj2011.0210

7. Beckie HJ, Harker KN (2017) Our top 10 herbicide-resistant weed management practices. Pest Management Science 73:1045-1052

8. Sousa NL, Cabral GB, Vieira PM, Baldoni AB, Aragão FJL (2017) Biodetoxification of ricin in castor bean (Ricinus communis L.) seeds. Sci Rep 7(15385). https://doi.org/10.1038/s41598-017-15636-7

9. Aragão FJL, Sarokin L, Vianna GR, Rech EL (2000) Selection of transgenic meristematic cells utilizing a herbicidal molecule results in the recovery of fertile transgenic soybean [Glycine max (L.) Merril] plants at a high frequency. Theor Appl Genet 101:1-6

10. Shaner DL, Anderson PC, Stidham MA (1984) Imidazolinones: potent inhibitors of acetohydroxyacid synthase. Plant Physiol 76:545-546. https://doi.org/10.1104/pp.76.2.545 PMID: 16663878

11. Baldoni $A B$, Araújo ACG, Carvalho MH, Gomes ACMM, Aragão FJL (2010) Immunolocalization of ricin accumulation during castor bean (Ricinus communis L.) seed development. Int. J Plant Biol 1(e12):61-65. https://doi. org/10.4081/pb.2010.e12

12. Jefferson RA, Kavanagh TA, Bevan MW (1987) GUS fusions: $\beta$-glucuronidase as a sensitive and versatile gene fusion marker in higher plants. EMBO J 6:3901-3907

13. Tan S, Evans RR, Dahmer ML, Singh BK, Shaner DL (2004) Imidazolinonetolerant crops: history, current status and future. Pest Manag Sci 61(3):246-257. https://doi.org/10.1002/ps.993

14. Stuart RM, Romão AS, JL P-KAAA, Araújo WL (2010) Culturable endophytic filamentous fungi from leaves of transgenic imidazolinone-tolerant sugarcane and its non-transgenic isolines. Arch Microbiol 192:307-313. https://doi.org/10.1007/s00203-010-0557-9

15. Vianna GR, Aragão FJ, Rech EL (2011) A minimal DNA cassette as a vector for genetic transformation of soybean (Glycine max). Gen Mol Res 10(1):382-390

16. Kishchenko EM, Komarnitskii IK, Kuchuk NV (2011) Transgenic sugar beet tolerant to imidazolinone obtained by Agrobacterium-mediated transformation. Cytol Genet 45:148-152. https://doi.org/10.3103/S009545271 1030030

17. Citadin CT, Cruz ARR, Aragão FJL (2013) Development of transgenic imazapyr-tolerant cowpea (Vigna unguiculata). Plant Cell Rep 32:537-543

18. Bonfim K, Faria JC, Nogueira EOPL, Mendes EA, Aragão FJL (2007) RNAi-mediated resistance to Bean Golden Mosaic Virus in genetically engineered common bean (Phaseolus vulgaris). Mol Plant Microbe Interact 20:717-726

19. Yan S, Ren B, Zeng B, Shen J (2020) Improving RNAi efficiency for pest control in crop species. BioTechniques 68:283-290. https://doi.org/10. 2144/btn-2019-0171

\section{Publisher's Note}

Springer Nature remains neutral with regard to jurisdictional claims in published maps and institutional affiliations. 